\title{
Ethnomedicinal survey of indigenous medicinal plants in Jos Metropolis, Nigeria
}

\begin{tabular}{|c|c|}
\hline $\begin{array}{l}\text { Authors: } \\
\text { Babajide C. Fa } \\
\text { Victoria I. Josh } \\
\text { Temitope I. Og } \\
\text { Wilfred O. Mb }\end{array}$ & $\begin{array}{l}\text { emara }^{1} \text { (D) } \\
\text { ua }^{2} \text { (D) } \\
\text { unkanmi² (D) } \\
\text { eng }^{3} \text { (D) }\end{array}$ \\
\hline $\begin{array}{l}\text { Affiliations: } \\
{ }^{1} \text { Research Coo } \\
\text { Forestry Resea } \\
\text { Nigeria, Ibada }\end{array}$ & $\begin{array}{l}\text { dinating Unit, } \\
\text { rch Institute of } \\
\text {, Nigeria }\end{array}$ \\
\hline $\begin{array}{l}{ }^{2} \text { Department } \\
\text { Federal Colleg } \\
\text { Jos, Nigeria }\end{array}$ & $\begin{array}{l}\text { Forestry, } \\
\text { of Forestry, }\end{array}$ \\
\hline $\begin{array}{l}{ }^{3} \text { Department } \\
\text { Environmenta } \\
\text { Faculty of Agri } \\
\text { Natural Scienc } \\
\text { of Mpumalang } \\
\text { South Africa }\end{array}$ & $\begin{array}{l}\text { f Biology and } \\
\text { Sciences, } \\
\text { culture and } \\
\text { es, University } \\
\text { a, Mbombela, }\end{array}$ \\
\hline $\begin{array}{l}\text { Correspondin } \\
\text { Wilfred Mben } \\
\text { wilfred.mbeng }\end{array}$ & $\begin{array}{l}\text { author: } \\
\text { @ump.ac.za }\end{array}$ \\
\hline $\begin{array}{l}\text { Dates: } \\
\text { Received: } 04 \mathrm{~J} \\
\text { Accepted: } 30 \mathrm{~J} \\
\text { Published: } 27\end{array}$ & $\begin{array}{l}\text { une } 2021 \\
\text { uly } 2021 \\
\text { Pct. } 2021\end{array}$ \\
\hline $\begin{array}{l}\text { How to cite th } \\
\text { Falemara, B.C. } \\
\text { Ogunkanmi, T. } \\
\text { W.O., 2021, 'E } \\
\text { survey of indig } \\
\text { medicinal plar } \\
\text { Metropolis, Ni } \\
\text { of Medicinal P } \\
\text { Economic Dev } \\
\text { a128. https:// } \\
\text { 10.4102/jomp }\end{array}$ & $\begin{array}{l}\text { is article: } \\
\text { Joshua, V.I., } \\
\text { \& Mbeng, } \\
\text { hnomedicinal } \\
\text { enous } \\
\text { ts in Jos } \\
\text { geria', Journal } \\
\text { ants for } \\
\text { lopment 5(1), } \\
\text { loi.org/ } \\
\text { d.v5i1.128 }\end{array}$ \\
\hline $\begin{array}{l}\text { Copyright: } \\
\text { (C) 2021. The A } \\
\text { Licensee: AOS } \\
\text { is licensed unc } \\
\text { Creative Comr } \\
\text { Attribution Lic }\end{array}$ & $\begin{array}{l}\text { uthors. } \\
\text { S. This work } \\
\text { er the } \\
\text { ions } \\
\text { ense. }\end{array}$ \\
\hline Read online: & \\
\hline 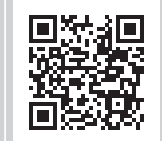 & $\begin{array}{l}\text { Scan this QR } \\
\text { code with your } \\
\text { smart phone or } \\
\text { mobile device } \\
\text { to read online. }\end{array}$ \\
\hline
\end{tabular}

Background: Indigenous knowledge is progressively fading out because of a lack of proper record-keeping, as the knowledge is transmitted verbally. There is, therefore, a dire need for preserving this valuable knowledge by ensuring proper documentation and sharing of traditional knowledge.

Aim: This research study sought to explore the indigenous knowledge used by herbal medicine practitioners for treating various human ailments in Jos Metropolis of Plateau State, Nigeria.

Setting: The study was conducted using a structured questionnaire administered to 100 registered traditional healers in Jos North LGA of Plateau State.

Methods: Selected medicinal plants were collected, pressed and transported to the Forestry Research Institute of Nigeria (FRIN), Ibadan for identification, authentication and deposition of voucher specimens for voucher number at FRIN herbarium, Ibadan. Descriptive statistics were used to analyse the ethnomedicinal data.

Results: Thirty-nine plant species, distributed in 33 families and 39 genera, were cited by the respondents. The Fabaceae was the most represented family, followed by the Euphorbiaceae and Myrtaceae. Leaves were the most used plant part (29\%), whilstthe most cited plant habit forms include trees $(48 \%)$ and herbs $(31 \%)$. The herbal remedies were mostly administered orally $(53 \%)$ and topically $(26 \%)$, whilst the most common method of preparation was decoction (42\%). The highest consensus factor (1.00) was detected for chickenpox or measles or leprosy, haemorrhoids and sickle cell ailments.

Conclusion: There is an existence of a wide gap in traditional healing knowledge between the elderly and the younger generations in the study area. The high fidelity level observed in this study implied a general acceptance and preferred usage of such herbal plants for the treatment of particular ailments.

Keywords: ethnomedicinal; survey; indigenous; medicinal plants; traditional healers; Jos; Nigeria.

\section{Introduction}

Ethnobotany is defined as the scientific study of how people of particular regions and cultures utilise plants in their local environments. These uses include medicines, food, fuel, shelter, cosmetics, clothing, rituals and religious ceremonies (Abera 2014). Ethnobotany, therefore, aims to describe, document and explain the complex relationships between culture and the uses of plants across various human societies. However, the native people usually harvest and exploit the plant resources around them unsustainably, which significantly affects the biodiversity and conservation of ecosystem resources at large (Adebayo-Tayo et al. 2010). Ethnobotany plays a critical role in the study of herbal medicine. This is because there is an inextricable link between peoples' cultural heritage, indigenous traditions and nature, as well as between indigenous knowledge and conventional technology (Adebayo-Tayo et al. 2010). This by so doing provides better insight and detailed knowledge of herbal medicine. Nature, through medicinal herbs, bequeath human health with a treasured gift within our natural environment, such that humans significantly and directly benefit from ecosystem biodiversity (Upasania et al. 2017).

Ethnomedicine is a sub-discipline of ethnobotany that comprises the study of traditional medicines, especially for those whose knowledge and practice have been orally transmitted down from one generation to another. Ethnobotanical survey is an important strategy for the continuous search for natural plant products as medicines, and it serves as a major approach for the selection of plants for pharmacological screening. Also, the ethnomedicinal uses of plants remain one of the most 
important criteria in the search of novel therapeutic compounds by ethnopharmacologists and pharmaceutical companies.

Indigenous knowledge involving the use of herbal medicine for healing is progressively fading out because of a lack of proper record-keeping (Petros \& Nokwanda 2021), modernisation (Gakuya et al. 2020; Megenase, Gelaye \& Dara 2019) and language loss (Cámara-Leret \& Bascompte 2021). Knowledge is usually transmitted verbally from generation to generation without proper documentation (Gakuya et al. 2020; Petros \& Nokwanda 2021). Contributory threats to erosion in the knowledge of some of these valuable herbal plant resources include unscientific mode of collection, lack of sensitisation in harvesting regulations and conservation, deforestation, uncontrolled exploitation, transferring of herbal healers to other jobs and environmental degradation (Abera 2014). There is, therefore, the dire need to preserve this endangered and valuable knowledge before they disappear by ensuring documentation, preservation and sharing of the traditional knowledge across communities (Kassim et al. 2016). Indigenous knowledge of medicinal plants by traditional healers is significant for healthcare delivery in rural communities, and may serve as leads for the discovery and synthesis of novel drugs with alternative mechanisms of action (Pei 2005). Hence, proper documentation of indigenous knowledge is vital to help researchers to investigate and characterise herbal plants with active ingredients for treating chronic ailments and for the benefits of humanity (Abera 2014).

Whilst most urban communities depend on conventional medicine (because of modernisation and civilisation) to meet their health needs, the majority of rural communities still depend on traditional medicine (Jimam et al. 2015). This over-reliance on traditional medicine by local communities has been explained by the fact that it is a core component of the custom, ethos or tradition of the people who use it. Secondly, traditional medicine is economical, and many pharmaceutical drugs are not affordable by the majority of poor people in local communities. For example, it is estimated that only about $20 \%$ of malaria cases are treated in the primary healthcare centre (PHCs) in Nigeria because primary healthcare facilities for malaria management are very limited in rural areas (Jimam et al. 2015). The PHC is the entry point into the healthcare sector of Nigeria and is aimed at providing healthcare services in rural communities. On the positive side, the diversity and richness of the African flora serve as a reservoir and inexhaustible source of therapies for a myriad of ailments. Africa has rich biodiversity resources with about 45000 species of plant, out of which 5000 species are used for medicinal purposes and many remain untapped (Afolayan, Grierson \& Mbeng 2014). Unfortunately, these natural resources and their associated indigenous or traditional ecological knowledge are being subjected to threats that are promulgated by cultural and environmental changes, thus, highlighting the need for the preservation of local knowledge and medicinal plants in the natural ecosystems. This can be achieved partly through ethnobotanical studies. This study, therefore, sought to explore the indigenous knowledge used by herbal medicine practitioners in Jos Metropolis in Plateau State Nigeria for treating various human ailments.

\section{Materials and methods Study area}

The research study was conducted in Jos North Local Government Area (LGA) of Plateau state (Figure 1), with a population density of 439217 constituting 220856 men and 216361 women (National Population Commission 2006). Jos North LGA has a land area of $291 \mathrm{~km}^{2}$ inhabited by various ethnic groups, such as Irigwe, Berom, Ngas, Anaguta, Rukuba and Mwaghavul, as well as different tribes, including Fulani, Hausa, Igbo and Yoruba.

\section{Ethnomedicinal investigation}

This study focused on traditional healers who use medicinal plants for the treatment of various human ailments in Jos North LGA. This was conducted through interviews and discussions with 100 traditional healers who were registered with the traditional healers' association, Jos North LGA. The choice of the sample size and the purposive selection were based on a reconnaissance survey and interview, which were conducted before the study.

The interviews and discussions were conducted in the local languages of the traditional healers (Hausa, Yoruba and Igbo) using a well-structured questionnaire. The questionnaires consisting of both open-ended and closedended questions were administered to the respondents. Interview or discussion themes targeted the names of the common diseases or disorders, local names of the medicinal plants, life form, the plant parts used, method of preparation and administration of the herbal medicine. Where necessary, the aetiology and symptomatology of some diseases were described to the traditional healers in order to enable them to recollect the exact medicinal plants that they usually use to manage the diseases. The authenticity of claims was verified by cross-checking the acquired data in different locations either by showing the medicinal plants or telling the local names to other informants (Afolayan et al. 2014). The medicinal use of a particular plant was validated only when the answers of two or more traditional healers coincided with the same use of a similar part of the plant, irrespective of the method of preparation. Data were also obtained from secondary sources, such as relevant literature, books, journals, conference proceedings, newspapers, magazines and online sources. The results of the study are tabulated to include scientific or botanical name, plant family, local name, plant part used, and method of preparation and application.

\section{Identification and preservation of voucher specimens of medicinal plants}

The traditional healers assisted in the collection of the cited medicinal plants to ensure that the correct plants were 


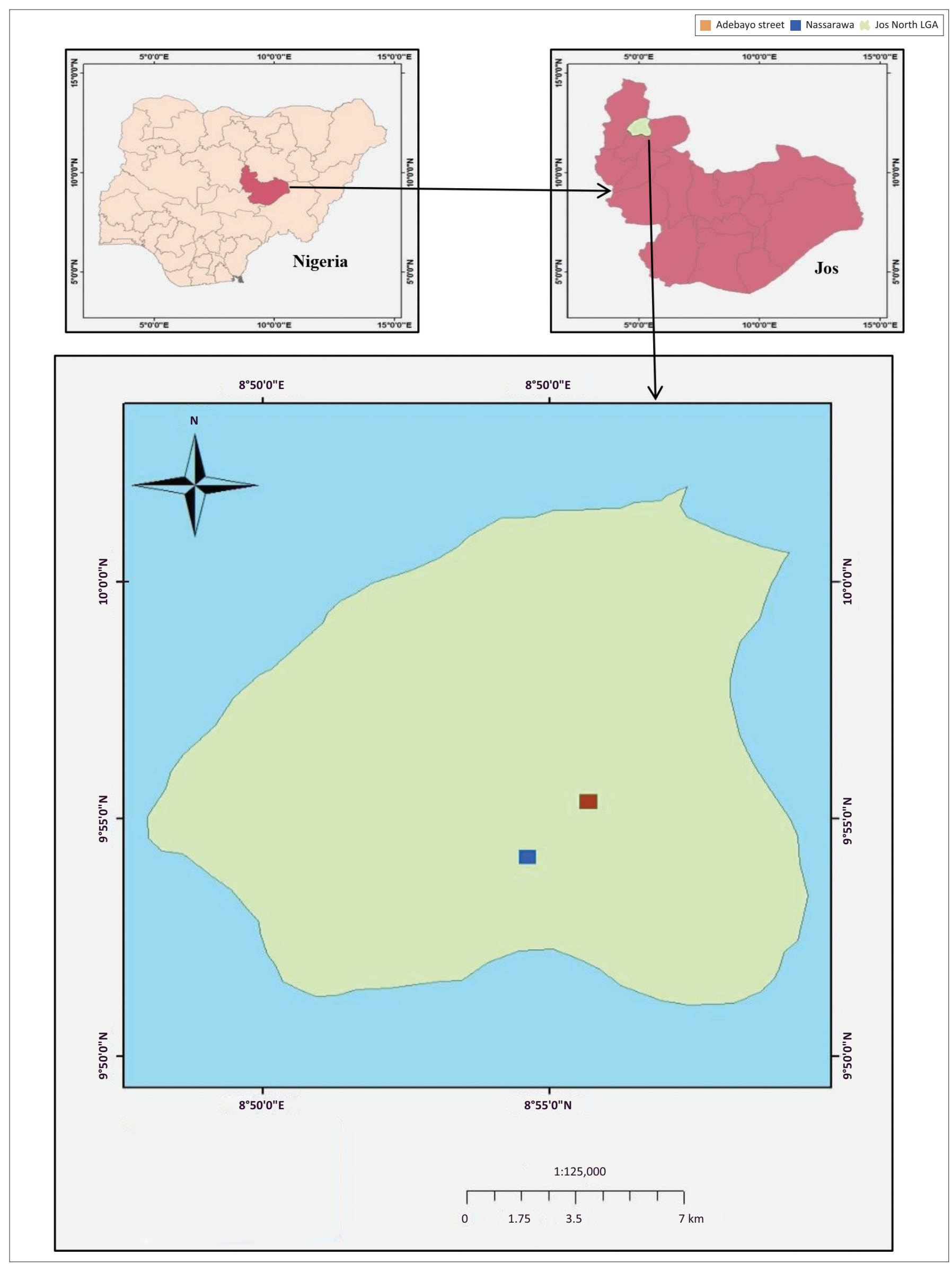

Source: Digital map of Nigeria, 2018.

FIGURE 1: Map of Nigeria showing the location of research study. 
collected. The fresh specimens of the collected medicinal plants were pressed and later transported to the Forestry Research Institute of Nigeria (FRIN), Ibadan, where they were identified by botanists using floristic works of Nigeria. Voucher specimens were deposited at FRIN herbarium, Ibadan.

\section{Data analysis}

Descriptive statistics, such as means and percentages, were used for the demographical information of the respondents, whilst two analytical tools (informant consensus factor [ICF] and fidelity level [FL]) were used to analyse the ethnomedicinal data that were obtained during the study.

\section{Informant consensus factor}

The user's variability of herbal plants was determined using the informant or respondent consensus factor $\left(\mathrm{F}_{\mathrm{IC}}\right)$ with the method of Heinrich et al. (2001) and Canales et al. (2005). The consensus value ranged between 0 and 1 . According to Heinrich et al. (2009), high value connotes high usage of one or few plant species to treat a specific ailment, whilst a low value indicates disagreement between informants over the use of any particular plant. Informant consensus factor was obtained from Eqn 1:

$\mathrm{ICF}=\frac{N_{\mathrm{ur}}-N_{\mathrm{t}}}{N_{\mathrm{ur}}-1}$,

[Eqn 1]

where $N_{\text {ur }}$ refers to the number of individual plant use reports for a certain illness category, whilst $N_{\mathrm{t}}$ connotes the total number of herbal species utilised by all respondents for this illness category.

\section{The fidelity level}

The potency of a particular medicinal plant to treat or heal an ailment in a cultural group was quantified using the FL. Fidelity level is derived from the comparative healing power of the herbal plant species concerning the proportion of respondents' agreement on the usage of a particular medicinal plant for treatment against a specific ailment category (Teklehaymanot 2009). However, reported diseases were classified into major ailment categories before the determination of the FL (Heinrich et al. 2001). Fidelity level was obtained from Eqn 2:

$$
\mathrm{F}_{\mathrm{L}}(\%)=\frac{N_{\mathrm{P}}}{N} \times 100
$$

where ' $N$, refers to the number of respondents who claimed using a medicinal plant to treat a given disease or some major ailments, whilst ' $N$ ' connotes the number of respondents who use the plants as a medicine to treat any specific disease or ailment.

\section{Ethical considerations}

Ethical clearance and approval for the research study were obtained from the Forestry Research Institute of Nigeria's ethics committee.

\section{Results and discussion Demographic information}

The demographic information of the traditional healers who participated in the study is presented in Table 1. Close to half of the respondents $(47 \%)$ were in the age range of 51-60 years and $30 \%$ were with the age bracket of 61-70 years. Generally, the majority of the respondents were older than 51 years. Amongst the respondents, $62 \%$ were men, whilst 38\% were women. Most of the traditional healers practised Islamic religion $(60 \%)$, whilst $35 \%$ of them professed Christianity. However, $78 \%$ of the traditional healers had formal education. Majority of the traditional healers have been engaged in this practice for last $7-10$ years (31\%), whilst $47 \%$ and $27 \%$ of them have their own private jobs and personal businesses, respectively.

As observed in this study, the traditional healers were within the age brackets of 51-60 years, that is, generally above 51 years. In a similar consonance, the study also reported that elders (> 60 years) were the ones who possess significant traditional knowledge and were practising traditional medicine. As similarly reported (Cheikhyoussef et al. 2011; Mahwasane, Middleton \& Boaduo 2013), elders above 60 years are usually endowed with significant traditional knowledge

TABLE 1: Demographic characteristics of the traditional healers.

\begin{tabular}{|c|c|c|}
\hline Respondent variable & Description & Response (\%) \\
\hline \multirow[t]{6}{*}{ Age (years) } & $31-40$ & 4 \\
\hline & $41-50$ & 12 \\
\hline & $51-60$ & 47 \\
\hline & $61-70$ & 30 \\
\hline & $\geq 71$ & 7 \\
\hline & Total & 100 \\
\hline \multirow[t]{3}{*}{ Gender } & Male & 62 \\
\hline & Female & 38 \\
\hline & Total & 100 \\
\hline \multirow[t]{4}{*}{ Religion } & Islam & 60 \\
\hline & Christianity & 35 \\
\hline & Traditional & 5 \\
\hline & Total & 100 \\
\hline \multirow[t]{3}{*}{ Educational status } & No formal education & 22 \\
\hline & Has formal education & 78 \\
\hline & Total & 100 \\
\hline \multirow[t]{6}{*}{ Duration of practice (years) } & $3-6$ & 8 \\
\hline & $7-10$ & 31 \\
\hline & $11-14$ & 26 \\
\hline & $15-18$ & 15 \\
\hline & $\geq 18$ & 20 \\
\hline & Total & 100 \\
\hline \multirow[t]{5}{*}{ Occupational status } & Government Job & 2 \\
\hline & Private Job & 47 \\
\hline & Business & 27 \\
\hline & Farming & 24 \\
\hline & Total & 100 \\
\hline
\end{tabular}


and practice of traditional medicine. This consequently validates the fact that a wide gap exists between the elderly and the younger generation on the knowledge of traditional healing (Ohemu et al. 2014). This finding also suggests that the legacy of traditional knowledge in the study area is endangered, especially if the knowledge is not being passed by the elders to the younger generation. However, Shapi, Matengu and $\mathrm{Mu}$ Ashekele (2009) posited that with regard to traditional knowledge, a considerable period is required for the indigenous people to acquire the inherent knowledge of traditional healing.

The findings of Arowosegbe, Olanipekun and Kayode (2015), however, contradict with those of this present investigation. They reported that the age bracket of 61 years and above had the least number of traditional medicine practitioners in Ekiti State, Nigeria. This could be ascribed to the fact that locality can be a determinant factor in the integration of new healers in traditional medicine practices. In consonance with the report of findings of Regassa (2013) and Arowosegbe et al. (2015), men are more involved in traditional medicine practices than women. This negates the assertion of Cheikhyoussef et al. (2011), who reported more female (70\%) traditional healers than male $(30 \%)$.

\section{Diversity of medicinal plants utilised by the traditional healing practitioners}

The medicinal plants cited in this investigation are presented in alphabetical order, including their botanical and local names, plant parts used, methods of preparation and administration, as shown in Table 2. Thirty-nine plant species, distributed in 33 families and 39 genera, were cited by the respondents as being used in the treatment of one or more ailments. The Fabaceae was the most representative family with three species, followed by the Euphorbiaceae and Myrtaceae with two species each.

\section{Plant parts used, habits, methods of administration and preparation of the medicinal plants}

Leaves (29\%) and tree bark (23\%) were the most commonly used plant parts for treatment. Other plant parts include seeds $(13 \%)$, fruit $(13 \%)$, roots $(11 \%)$, flowers $(9 \%)$ and pulp (2\%) (Figure 2). Out of the 39 plant species cited for the treatment of diverse ailments by the traditional healers, $48 \%$ were trees, $31 \%$ were herbs and $21 \%$ included shrubs (Figure 3 ). The herbal remedies (Figure 4) were mostly administered orally (53\%) and topically (26\%) (Figure 5), whilst the most common method of preparation was decoction (42\%), followed by maceration (25\%), pounding (16\%), crushing (9\%) and chewing (8\%).

Amongst the plant parts used against various ailments in the study area, leaves and barks are reported to be the most frequently used (Figure 6), contrary to the findings of Steenkamp (2003) and Shrivastava (2013) who both reported a high frequency of roots plant parts. The observed inference of high frequency of leaves can be attributed to the ease of collection and processing of abundant quantities (Rehmana et al. 2017; Tugume et al. 2016). This occurrence can also be ascribed to existence of biologically active compounds against diseases, compared with other plant parts (Faruque et al. 2018; Passulacqua et al. 2007). The leaf area of any plant constitutes the major photosynthetic area and the most metabolically active part - this enhances the production of secondary metabolites (through various biochemical pathways), which are responsible for its healing potential (Ghorbani 2005).

Majority of the herbal remedies in the study area were sourced from trees, contradicting the reports of Tumoro and Maryo (2016) and Faruque et al. (2018) that herbs were the most common life forms. From a conservationist perspective, the exploitation of leaves from trees is more sustainable as opposed to herbs because trees are more resilient, probably because of their large sizes. Notwithstanding, the harvesting of leaves should be regulated - harvesting in large quantities is destructive as it restrains the physiological processes in flowers, seeds and fruits, and this subsequently affects the regeneration potential of the plant (Tugume et al. 2016).

The administration of the herbal medicine mostly by oral means, as well as through topical, nasal and optical routes, corroborates previous findings (Kankara et al. 2015; Keo et al. 2018; Tugume et al. 2016; Tumoro \& Maryo 2016; Umair, Altaf \& Abbasi 2017). A high frequency of oral administration as reported was believed to be associated with the easy conveyance of the herbal remedies, which are mixed with some solvents or additives (Tugume et al. 2016).

As revealed in the study findings, different methods of herbal drug preparation were utilised by the traditional healers, which ranged (in ascending order) from decoction, maceration, pounding, crushing to chewing. Decoction was found to be the widely adopted method as corroborated by similar findings (Afolayan et al. 2014; Keo et al. 2018; Tugume et al. 2016; Umair et al. 2017). Conversely, Tumoro and Maryo (2016) and Habtamu, Mulatu and Tsdeke (2014) reported crushing, whilst Faruque et al. (2018) indicated paste as the most popular mode of herbal medicine preparation. Nonetheless, decoction is generally utilised in preparing herbal remedies because of the ease of preparation, in which the medicinal plant is boiled in a solvent, such as water, soup and tea (Rokaya, Münzbergová \& Timsina 2010). Hot extraction by boiling was found to have more efficacy compared with cold extraction as it helps to preserve the efficacy of the herbal decoction over a long time (Hirt \& M'pia 2008).

\section{Consensus factor amongst the traditional healers}

The diseases that were mentioned by the traditional healers and their ICFs, as shown in Table 3, were classified into seven categories: blood-related ailments, skin diseases, skeletal, gastrointestinal, STDs or genital, respiratory and others, and 


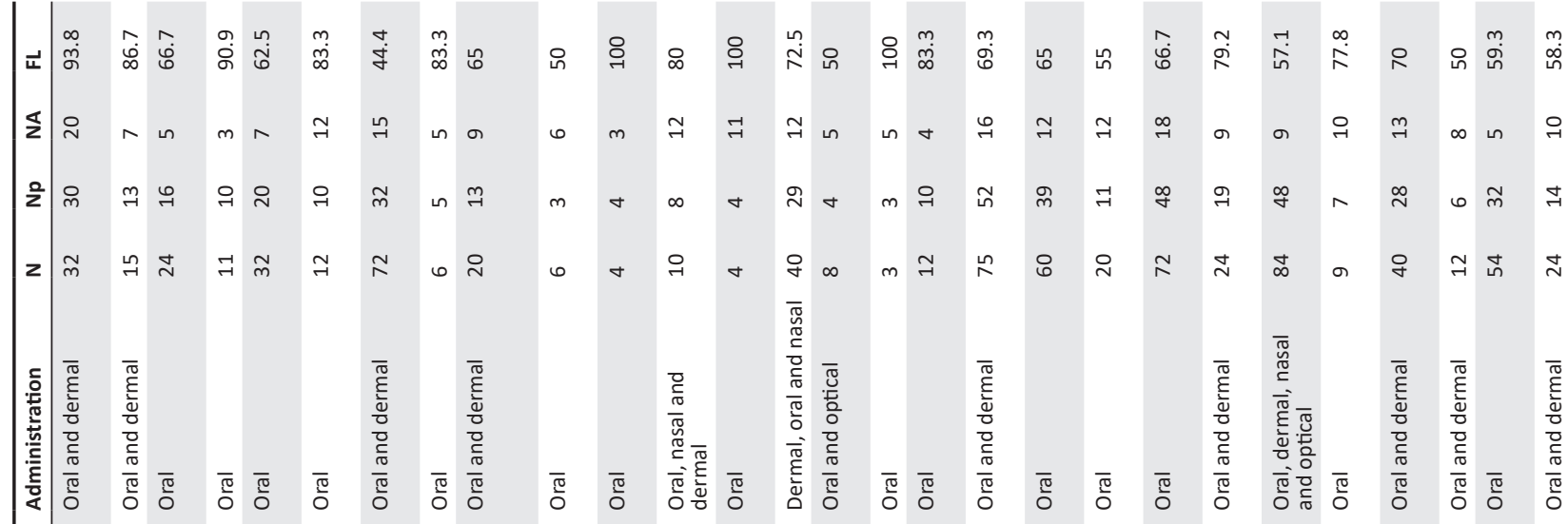

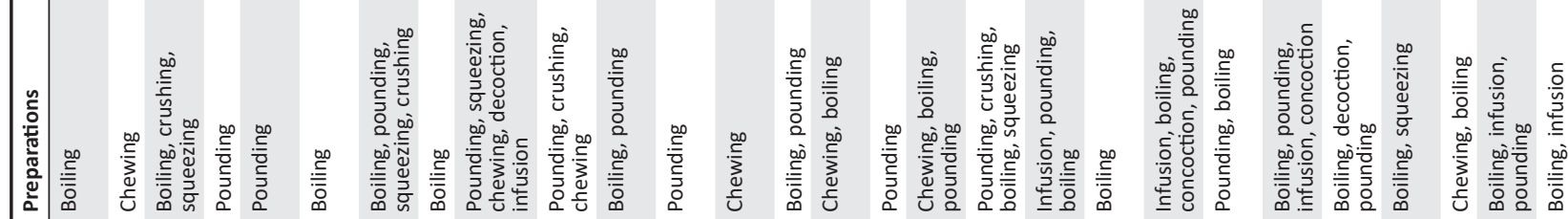

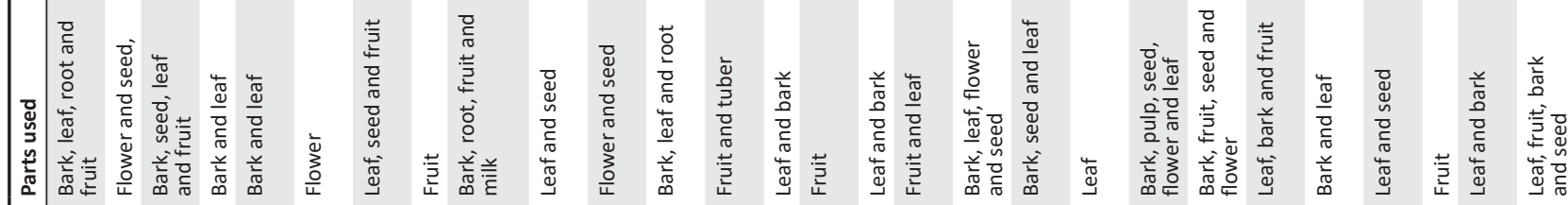

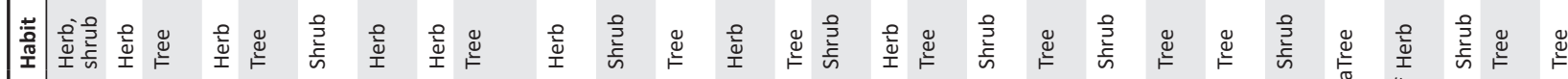

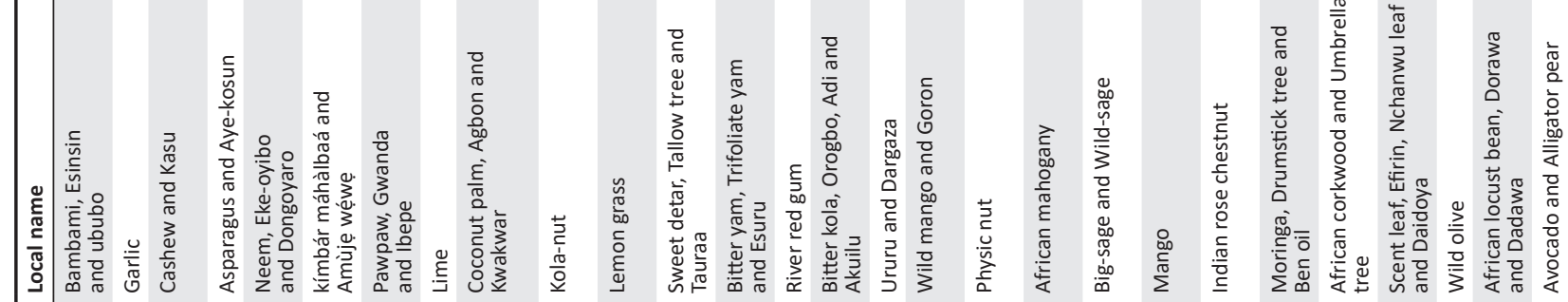

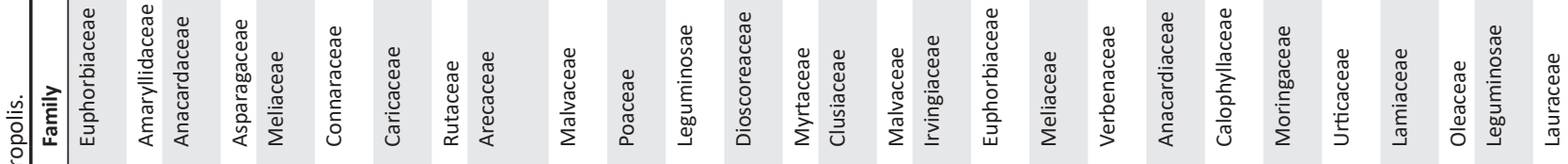

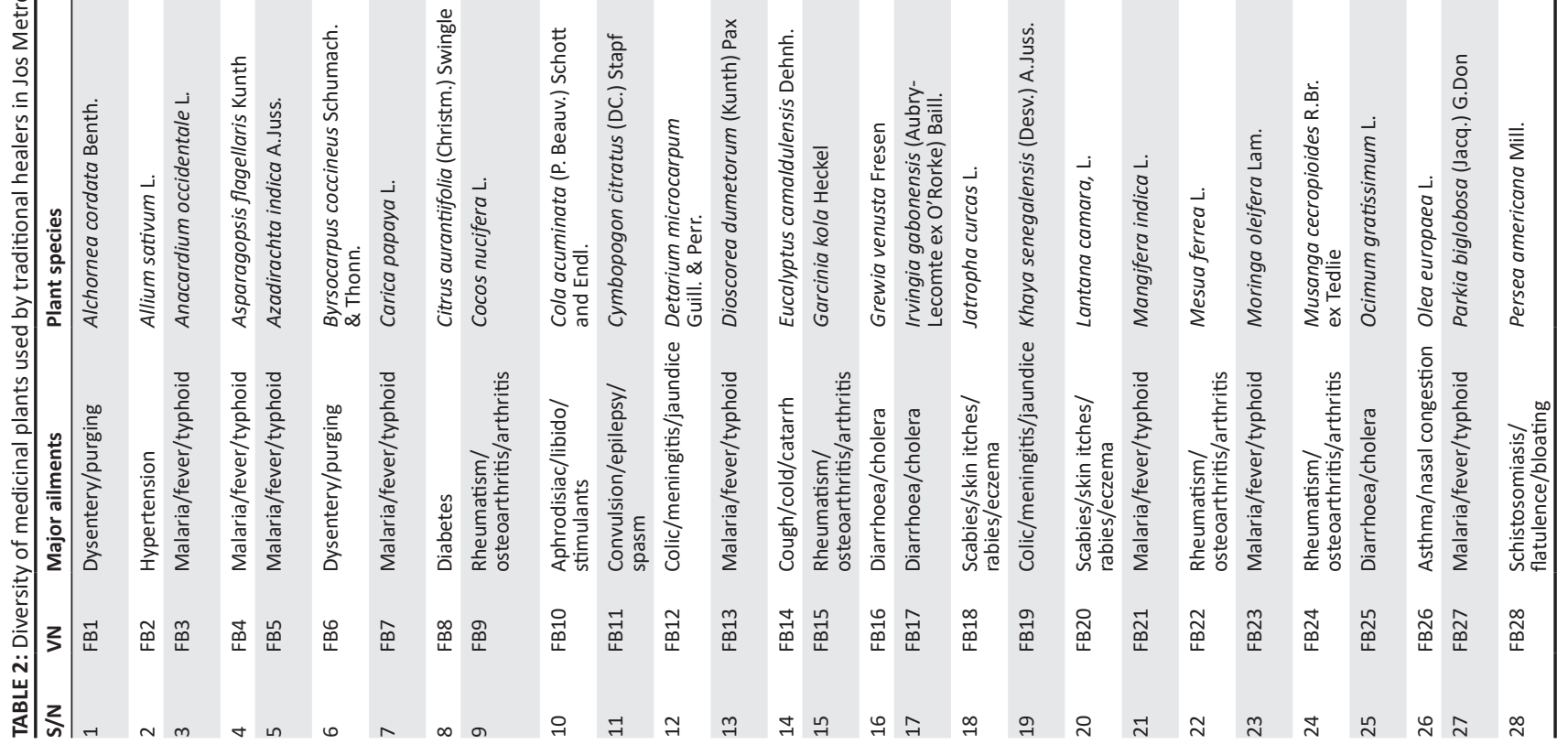




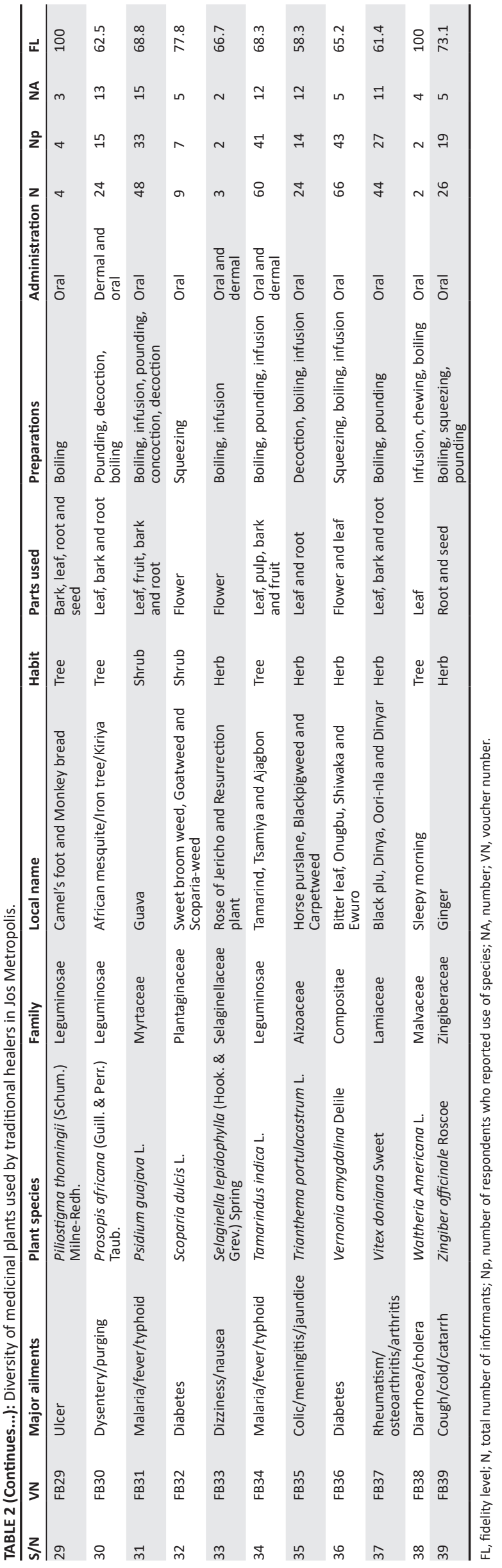

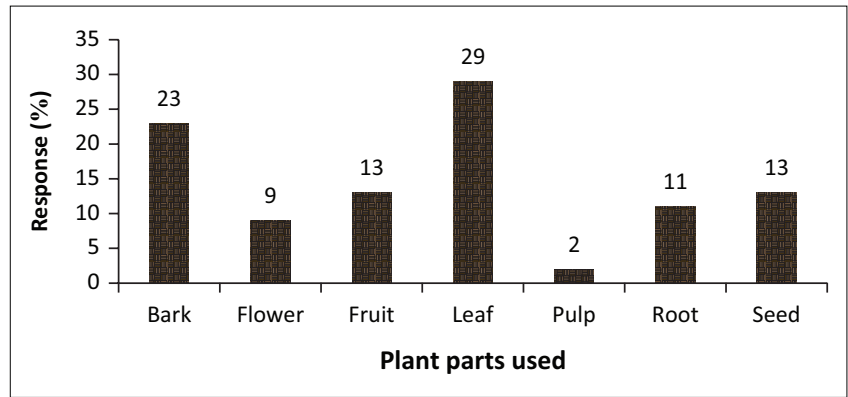

FIGURE 2: Plant parts used.

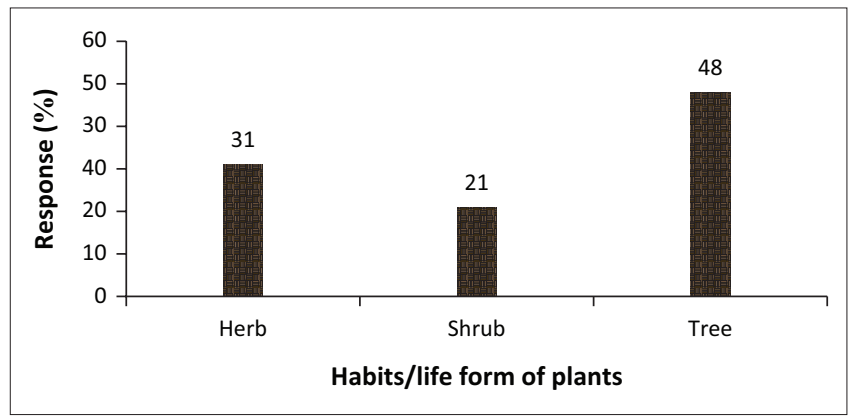

FIGURE 3: Habits or life forms of the plant species used by the traditional healers.

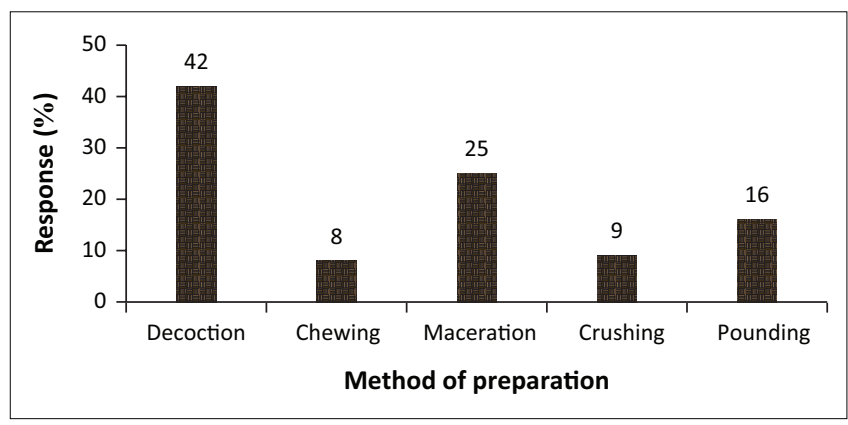

FIGURE 4: Methods of preparation of the herbal remedies.

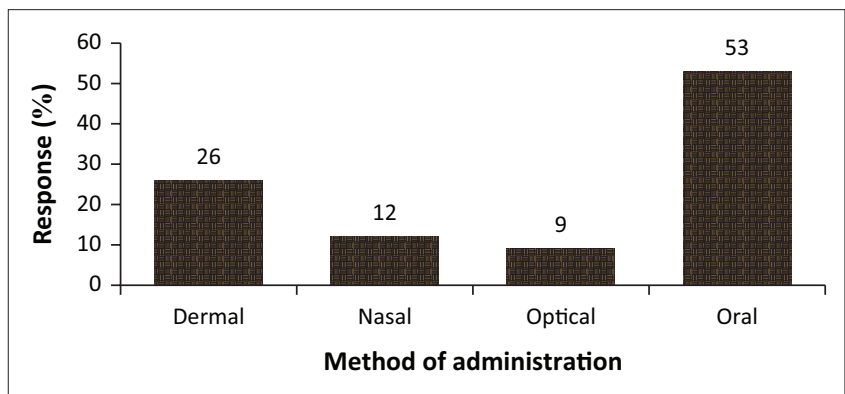

FIGURE 5: Mode of administration of the herbal remedies.

their ICFs ranged from 0.33 to 1 . The highest consensus factor (1.00) was detected for chickenpox or measles or leprosy (four use reports), haemorrhoids (two use reports), and sickle cell ailments (two use reports). The lowest ICFs were revealed for the following categories of ailments, such as paralysis or stroke (ICF $=0.60$; six use reports), ulcer (ICF $=0.50 ; 13$ use reports) and cancer (ICF $=0.33$; four use reports). Malaria or fever had the highest number of use reports (180), followed by diarrhea or cholera (71) and rheumatism or arthritis (70). However, the lowest use reports were observed for 


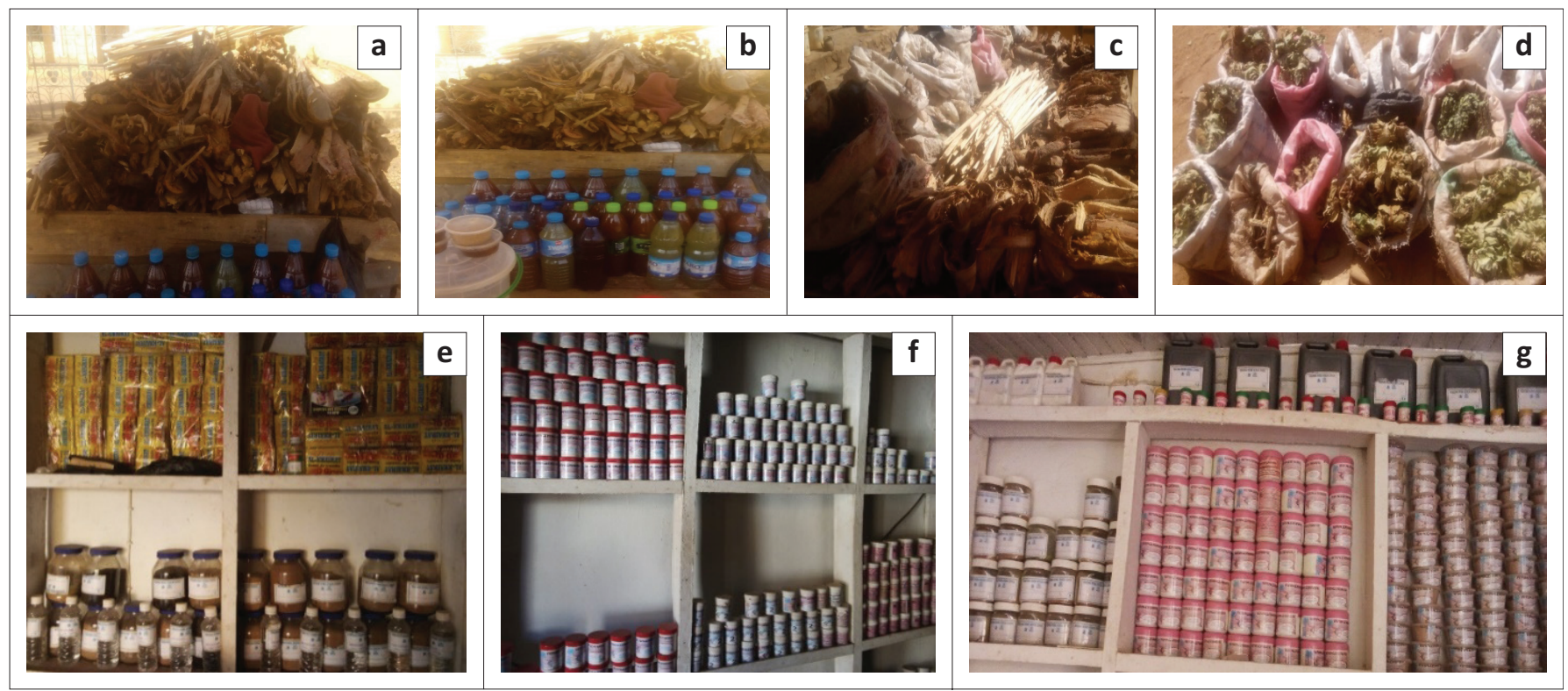

FIGURE 6: Refined herbal drugs (a-g) marketed by traditional healers in the study area.

haemorrhoids (2), sickle cell (2), chickenpox or measles or leprosy (4) and cancer (4). Malaria or fever (20), diarrhea or cholera (17), dysentery or purging (15), and rheumatism or osteoarthritis or arthritis (15) had the highest number of medicinal plant species (Table 3).

The level of agreement by the respondents in using a particular medicinal plant for treating several ailment categories (Rehmana et al. 2017), as well as a means of establishing the most widely used plant species for the treatment of various diseases (Chekole 2017), is measured by ICF. Higher ICF ( 0.67 and 1$)$ indicates ailments with a high frequency of prevalence in the study location. According to Kankara et al. (2015), this high ICF might be attributed to the efficacy of the plants in providing a remedy to the reported diseases. It can also be ascribed to communication and sharing of information on the potency of the medicinal plants, prolonged usage and feedback on the effectiveness of the medicinal plants. Albeit, the highest ICF observed for chickenpox or measles or leprosy, haemorrhoids and sickle cell ailment categories (Table 3) with fewer use reports implies that information on medicinal treatments as regards these ailment categories are kept secret amongst the traditional healers (Chekole 2017). In contrast, the low ICF values reported for paralysis or stroke (0.60), ulcer (0.50) and cancer (0.33) revealed a gap in communication and knowledge usually common with herbal healers divulging information for fear of copyrights (Chekole 2017).

\section{Fidelity level}

As revealed in the study findings, the identified medicinal plants used for the treatment of different categories of ailments has FL ranging from $44.4 \%$ to $100 \%$. Cymbopogon citratus, Dioscorea dumetorum, Grewia venusta, Piliostigma thonningii and Waltheria americana revealed a 100\% FL (Table 2). Cola acuminate (50\%), Garcinia kola (50\%), Olea europaea (50\%) and Carica papaya (44.4\%) indicated the lowest FLs (Table 2).

Medicinal plants showing high FLs indicate higher pharmacological potentials because of the presence of potent phytochemicals, which requires further laboratory screening for the discovery of novel curing possibilities (HassanAbdallah et al. 2013). The percentage of FL (Table 2), as revealed in this study, ranged from $44.4 \%$ to $100 \%$. This aligns with the range of values $(45 \%-100 \%)$ affirmed by Rehmana et al. (2017). They also acknowledged high FLs amongst plant species such as Cymbopogon citratus, Dioscorea dumetorum, Grewia venusta, Piliostigma thonningii and Waltheria americana.

Cymbopogon citratus (Poaceae), commonly known as lemon grass, was cited by respondents as being used in the treatment of convulsion, epilepsy and spasms. Many plants that contain essential oils (EOs) have been reported to exhibit anticonvulsant activity and might benefit people with epilepsy (Bahr et al. 2019). For example, clove, lemon grass and lavender contain constituents, such as citral, carvone, linalool and eugenol, which are phytoconstituents with potential antiepileptic activity. Whilst further research studies are needed to confirm their modes of action, it seems that the anticonvulsant properties of EOs are mainly because of their ability to regulate the GABAergic system of neurotransmission and their capacity to change ionic currents via ion channels (Bahr et al. 2019). A decoction of the leaves of G. venusta and W. americana was reported to be used for the treatment of diarrhea and dysentery by the traditional healers in the study area. The Grewia genus (Tiliaceae) encompasses about 150 species of small shrubs and trees, distributed in tropical and subtropical regions of the world, and is the sole genus that yields edible fruits in the family (Zia-Ul-Haq et al. 2013). The genus is reputed to cure stomach upsets, intestinal and 
TABLE 3: Categories of ailments and their informant consensus factor.

\begin{tabular}{|c|c|c|c|c|c|}
\hline $\begin{array}{l}\text { Categories of } \\
\text { ailments }\end{array}$ & $\begin{array}{l}\text { Use citation } \\
\text { per category }\end{array}$ & Ailments & $\mathrm{Nt}$ & Nur & ICF \\
\hline \multirow[t]{3}{*}{ Skin ailments } & 33 & Chicken pox/measles/leprosy & 1 & 4 & 1.00 \\
\hline & & Scabies/skin itches/rabies/eczema & 2 & 16 & 0.93 \\
\hline & & Ulcer & 7 & 13 & 0.50 \\
\hline \multirow[t]{5}{*}{ Blood ailments } & 267 & Haemorrhoids & 1 & 2 & 1.00 \\
\hline & & Sickle cell & 1 & 2 & 1.00 \\
\hline & & Hypertension & 5 & 40 & 0.90 \\
\hline & & Malaria/fever & 20 & 180 & 0.89 \\
\hline & & Diabetes & 7 & 43 & 0.86 \\
\hline \multirow[t]{2}{*}{ Skeletal } & 80 & $\begin{array}{l}\text { Rheumatism/osteoarthritis/ } \\
\text { arthritis }\end{array}$ & 15 & 70 & 0.80 \\
\hline & & Lumbago/back pain & 3 & 10 & 0.78 \\
\hline \multirow[t]{2}{*}{ Respiratory } & 55 & Asthma/nasal congestion & 5 & 17 & 0.75 \\
\hline & & Cough/cold/catarrh & 7 & 38 & 0.84 \\
\hline \multirow[t]{3}{*}{ STDs/genital } & 76 & $\begin{array}{l}\text { Venereal diseases (STD/ } \\
\text { gonorrhoea/syphilis) }\end{array}$ & 9 & 33 & 0.75 \\
\hline & & $\begin{array}{l}\text { Urinary infections/vaginal } \\
\text { discharge }\end{array}$ & 4 & 24 & 0.87 \\
\hline & & Aphrodisiac/libido/stimulants & 7 & 19 & 0.67 \\
\hline \multirow[t]{3}{*}{ Gastrointestinal } & 143 & Diarrhoea/cholera & 17 & 71 & 0.77 \\
\hline & & Dysentery/purging & 15 & 67 & 0.79 \\
\hline & & $\begin{array}{l}\text { Schistosomiasis/flatulence/ } \\
\text { bloating }\end{array}$ & 2 & 5 & 0.75 \\
\hline \multirow[t]{6}{*}{ Others } & 74 & Convulsion/epilepsy/spasm & 3 & 10 & 0.78 \\
\hline & & Paralysis/stroke & 3 & 6 & 0.60 \\
\hline & & Dizziness/nausea & 2 & 10 & 0.89 \\
\hline & & Cataract/glaucoma & 3 & 18 & 0.88 \\
\hline & & Cancer & 3 & 4 & 0.33 \\
\hline & & Jaundice & 4 & 26 & 0.88 \\
\hline
\end{tabular}

ICF, Informant consensus factor; Nt, number of taxa; Nur, number of use reports; STD, Sexually Transmitted Diseases.

skin infections, and seem to have mild antibiotic properties (Zia-Ul-Haq et al. 2013). Waltheria americana is considered as one of the 10 most important medicinal plants in Hawaii used as an aspirin-like drug for the management of inflammatory conditions, and the plant has also been reported for the treatment of diarrhea by traditional healers in other parts of Nigeria (Zongo et al. 2013). The high FL, as revealed in this study, indicates a wide acceptance and preferred usage of such herbal plants in treating specific ailments (Bibi et al. 2014; Islam et al. 2014; Zhang et al. 2015).

\section{Conclusion and recommendations}

This research study was undertaken to explore the level of indigenous knowledge in using medicinal plants for the treatment of various human ailments in Jos Metropolis of Plateau State, Nigeria. The study revealed that a total of 39 plant species, distributed in 33 families and 39 genera, were cited by the respondents as being used in the treatment of one or more ailments. The Fabaceae was the most representative family, followed by the Euphorbiaceae and Myrtaceae. A wide gap, as identified, exists between the older and younger generations in the transfer of knowledge and information sharing. This needs to be proactively bridged over time to prevent total dearth in critical medicinal knowledge. As observed in this study, the high FL indicates wide acceptance and preferred usage of certain medicinal plants in treating particular ailments. This ethnobotanical research study has added knowledge and discoveries in indigenous herbal medicine, especially in the study location. The findings further validate the continued existence of traditional healing practices using natural herbal plants. As a result of unsustainable harvesting and exploitation of medicinal tree species, especially the vegetative and photosynthetic parts for medicinal use, there is the dire need for conservation and preservation of this endangered and valuable knowledge before they disappear. Traditional healing practitioners should be generally enlightened on the imperative importance of documentation, information and knowledge sharing for preservation of relevant information, which should be archived for the future generations.

\section{Acknowledgements Competing interests}

The authors have declared that no competing interest exists.

\section{Authors' contributions}

F.B.C. conceived the research idea, wrote the original draft of the manuscript, analysed the data, reviewed and edited the manuscript; J.V.I participated in the review and editing of the manuscript, as well as the supervision of the research survey; O.T.I. conducted the research survey and collected the research data; W.O contributed to writing, reviewing and editing of the article.

\section{Funding information}

This research received financial support from the National Research Foundation (Grant ID: 115754) and the University of Mpumalanga, South Africa.

\section{Data availability}

The authors confirm that the data supporting the findings of this study are available within the article.

\section{Disclaimer}

The views and opinions expressed in this article are those of the authors and do not necessarily reflect the official policy or position of any affiliated agency of the authors.

\section{References}

Abera, B., 2014, 'Medicinal plants used in traditional medicine by Oromo people, Ghimbi District, Southwest Ethiopia', Journal of Ethnobiology and Ethnomedicine 10(40), 1-15. https://doi.org/10/1186/1746-4269-10-40

Adebayo-Tayo, B.C., Adegoke, A.A., Okoh, A.I. \& Ajibesin, K.K., 2010, 'Rationalizing some medicinal plants used in the treatments of skin diseases', African Journal of Microbiology Research 4(10), 958-963. https://doi.org/10.5897/AJMR. 9000626

Afolayan, A.J., Grierson, D.S. \& Mbeng, W.O., 2014, 'Ethnobotanical survey of medicinal plants used in the management of skin disorders among the Xhosa communities of the Amathole District, Eastern Cape, South Africa', Journal of Ethnopharmacology 153(1), 220-232. https://doi.org/10.1016/j.jep.2014.02.023

Arowosegbe, S., Olanipekun, M.S. \& Kayode, J., 2015, 'Ethnobotanical survey of medicinal plants used for the treatment of diabetes mellitus in Ekiti south senatorial district, Nigeria', European Journal of Botany, Plant Sciences and Phytology 2(4), 1-8.

Bahr, T.A., Rodriguez, D., Beaumont, C. \& Allred, K., 2019, 'The effects of various essential oils on epilepsy and acute seizure: A systematic review', Evidence-Based Complementary and Alternative Medicine 62(16), 745. https://doi. org/10.1155/2019/6216745 
Bibi, T., Ahmad, M., Bakhsh Tareen, R., Mohammad Tareen, N., Jabeen, R., Rehman, S.U. et al., 2014, 'Ethnobotany of medicinal plants in district Mastung of Balochistan province-Pakistan', Journal of Ethnopharmacology 157, 79-89. https://doi.org/10.1016/j.jep.2014.08.042

Cámara-Leret, R. \& Bascompte, J., 2021, 'Language extinction triggers the loss of unique medicinal knowledge'. Proceedings of the National Academy of Sciences of United States of America 118(24), e2103683118. https://doi.org/10.1073/ pnas. 2103683118

Canales, M., Hernandez, T., Caballero, J., Romo de Vivar, A., Avila, G., Duran, A. et al., 2005, 'Informant consensus factor and antibacterial activity of the medicinal plants used by the people of San Rafael Coxcatlan, Puebla, Mexico', Journal of Ethnopharmacology 97(3), 429-439. https://doi.org/10.1016/j. jep.2004.11.013

Cheikhyoussef, A., Shapi, M., Matengu, K. \& Ashekele, H.M.U., 2011, 'Ethnobotanical study of indigenous knowledge on medicinal plant use by traditional healers in Oshikoto region, Namibia', Journal Ethnobiology and Ethnomedicine 7(1), 1-11. https://doi.org/10.1186/1746-4269-7-10

Chekole, G., 2017, 'Ethnobotanical study of medicinal plants used against human ailments in Gubalafto District, Northern Ethiopia', Journal of Ethnobiology and Ethnomedine 13(1), 1-29. https://doi.org/10.1186/s13002-017-0182-7

Faruque, M.O., Uddin, S.B., Barlow, J.W., Hu, S., Dong, S., Cai, Q. et al., 2018 'Quantitative Ethnobotany of Medicinal Plants Used by Indigenous Communities in the Bandarban District of Bangladesh', Frontiers in Pharmacology 40(9), 12. https://doi.org/10.3389/fphar.2018.00040

Gakuya, D.W., Okumu, M.O., Kiama, S.G., Mbaria, J.M., Gathumbi, P.K., Mathiu, P.M. et al., 2020, 'Traditional medicine in Kenya: Past and current status, challenges, and the way forward', Scientific African 8, e00360. https://doi.org/10.1016/j. sciaf.2020.e00360

Ghorbani, A., 2005, 'Studies on pharmaceutical ethnobotany in the region of Turkmen Sahra, north of Iran: (Part 1): General results', Journal of Ethnopharmacology 102(1), 58-68. https://doi.org/10.1016/j.jep.2005.05.035

Habtamu, A., Mulatu, O. \& Tsdeke, L., 2014, 'Traditional medicinal plants utilization, management and threats in Hadiya Zone, Ethiopia', Journal of Medicinal Plants Studies 2(2), 94-108.

Hassan-Abdallah, A., Merito, A., Hassan, S., Aboubaker, D., Djama, M. \& Asfaw, Z., 2013, "Medicinal plants and their uses by the people in the region of Randa, Djibouti', Journal of Ethnopharmacology 148(2), 701-713. https://doi. org/10.1016/j.jep.2013.05.033

Heinrich, M., Ankli, A., Frei, B., Weimann, C. \& Sticher, O., 2001, 'Medicinal plants in Mexico: Healers' consensus and cultural importance', Social Science and Medicine 47(11), 1859-1871. https://doi.org/10.1016/s0277-9536(98)00181-6

Heinrich, M., Edwards, S., Moerman, D.E. \& Leonti, M. 2009, 'Ethnopharmacological field studies: a critical assessment of their conceptual basis and methods', Journal of Ethnopharmacology 124(1), 1-17. https://doi.org/10.1016/j. jep.2009.03.043.

Hirt, H.M. \& M'pia, B., 2008, Natural medicine in the tropics, 3rd edn., Marianum Press, Kisubi.

Islam, M.K., Saha, S., Mahmud, I., Mohamad, K., Awang, K. \& Uddin, J.S., 2014, 'An ethnobotanical study of medicinal plants used by tribal and native people of
Madhupur forest area, Bangladesh', Journal of Ethnopharmacology 151(2), 921-930. https://doi.org/10.1016/j.jep.2013.11.056

Jimam, N.S., David, S., Galam, N.Z., Joseph, B.N. \& Buoye, O.S., 2015, 'Patients' perception of the quality of malaria treatment in primary health care centers of Jos and Environs', Medicinal Journal of DY Patil University 8(4), 441-446. https:// doi.org/10.4103/0975-2870.160782

Kankara, S.S., Ibrahim, M.H., Mustafa, M. \& Go, R., 2015, 'Ethnobotanical survey of medicinal plants used for traditional maternal healthcare in Katsina state, Nigeria', South African Journal of Botany 97, 165-175. https://doi.org/10.1016/j. sajb.2015.01.007

Kassim, D.H.A., Raduan, S.Z., Abdul Aziz, M.W., Chelum, H.A, Morni, A.A.M. \& Wahab, R.A., 2016, 'Indigenous knowledge of medicinal plants used and it's implication towards health-seeking behavior among the Melanau in Pulau Bruit, Sarawak, 136-145.

Keo, S., Chrin, B., Dim, D., Buth, B., Chea, S., Chan, R. et al., 2018, 'Ethnobotanical survey of medicinal plants used by traditional healers in Kampong Speu province, Cambodia', Asian Journal of Pharmacogn 2(1), 21-32.
Mahwasane, S.T., Middleton, L. \& Boaduo, N., 2013, 'An ethnobotanical survey of indigenous knowledge on medicinal plants used by the traditional healers of the Lwamondo area, Limpopo province, South Africa', South African Journal of Botany 88, 69-75. https://doi.org/10.1016/j.sajb.2013.05.004

Megenase, J.A., Gelaye, K.T. \& Dara, P.K., 2019, 'Indigenous knowledge and practices on medicinal plants used by local communities of Gambella Region, South West Ethiopia', International Journal of Tropical Disease \& Health 39(2), 1-14. https:// doi.org/10.9734/IJTDH/2019/v39i230203

National Population Commission, 2006, 'Population and Housing Census of the Federal Republic of Nigeria', Plateau State Priority Tables, pp. 1-2, Nationa Population Commission, Abuja.

Ohemu, T.L., Agunu, A., Olutu, P.N., Ajima, U., Dafam, D.G. \& Azilla, J.J., 2014 'Ethnobotanical survey of medicinal plants used in the traditional treatment of viral infections in Jos, Plateau State, Nigeria', International Journal of Medicinal and Aromatic Plants 4(2), 74-81.

Passulacqua, N.G., Guariera, P.M, \& De Fine, G., 2007, 'Contribution to the knowledge of folk plant medicine in Calabria region (Southern Italy)', Filoterapia. 78, 52-68.

Pei, S.J., 2005, 'Ethnobotany and modernization of traditional Chinese medicine', in Y. Thomas, M. Karki, K. Gurung \& D. Parajuli (eds.), Himalayan medicinal and aromatic plants, balancing, use and conservation, Ministry of Forest and Soil Conservation, HMG, Nepal.

Petros, D. \& Nokwanda, N.K., 2021, 'Preservation of traditional medicinal knowledge: Initiatives and techniques in rural communities in KwaZulu-Natal' Library Initiatives and techniques in rural comm
Philosophy and Practice. (e-journal) 17, 4824.

Regassa, R., 2013, 'Assessment of indigenous knowledge of medicinal plant practice Medicinal Plants Research 7(9), 517-535. https://doi.org/10.5897/JMPR12.1126

Rehmana, M.N., Ahmada, M., Sultanaa, S., Zafara, M. \& Edwards, S., 2017, 'Relative popularity level of medicinal plants in Talagang, Punjab Province, Pakistan', Revista Brasileira de Farmacognosia 27(6), 751-775. https://doi.org/10.1016/j.bjp.2017.09.004

Rokaya, M.B., Münzbergová, Z. \& Timsina, B., 2010, 'Ethnobotanical study of medicinal plants from the Humla district of western Nepal', Journal of Ethnopharmacology plants from the Humla district of western Nepal', Journal of
130(3), 485-504. https://doi.org/10.1016/j.jep.2010.05.036

Shapi, M., Matengu, K. \& Mu Ashekele, H., 2009, Indigenous knowledge system pilot study-Oshikoto region, Multidisciplinary Research Centre, University of Namibia, Windhoek.

Shrivastava, A., 2013, 'Ethnomedicinal plants used for treatment of gynecological disorders by tribal of Dindori district of Madhya Pradesh', International Journal of Pharmacy and Life Science 40(12), 3185-3189.

Steenkamp, V., 2003, 'Traditional herbal remedies used by South African women for gynaecological complaints', Journal of Ethnopharmacology 86(1), 97-108. https:// gynaecological complaints', Journal of Eth
doi.org/10.1016/s0378-8741(03)00053-9

Teklehaymanot, T., 2009, 'Ethnobotanical study of knowledge and medicinal plants use by the people in Dek Island in Ethiopia', Journal of Ethnopharmacology 124(1), 69-78. https://doi.org/10.1016/j.jep.2009.04.005

Tugume, P., Kakudidi, E.K., Buyinza, M., Namaalwa, J., Kamatenesi, M., Mucunguzi, P. et al., 2016, 'Ethnobotanical survey of medicinal plant species used by communitie around Mabira Central Forest Reserve, Uganda', Journal of Ethnobiology and Ethnomedicine 12(5), 1-28. https://doi.org/10.1186/s13002-015-0077-4

Tumoro, G. \& Maryo, M., 2016, 'Determination of informant consensus factor and fidelity level of ethnomedicinal plants used in Misha Woreda, Hadiya Zone, Southern Ethiopia', International Journal of Biodiversity and Conservation 8(12), 351-364. https://doi.org/10.5897/IJBC2016.1020

Umair, M., Altaf, M. \& Abbasi, A.M., 2017, 'An ethnobotanical survey of indigenous medicinal plants in Hafizabad district, Punjab-Pakistan', PLoS One 12(6), e0177912. https://doi.org/10.1371/journal.pone.0177912

Upasania, S.V., Beldarb, V.G., Tatiyab, A.U., Upasanic, M.S., Suranab, S.J. \& Patil, D.S., 2017 'Ethnomedicinal plants used for snakebite in India: A brief overview', Integrative Medicine Research 6(2), 114-130. https://doi.org/10.1016/j.imr.2017.03.001

Zhang, L., Zhang, Y., Pei, S., Geng, S., Wang, C. \& Yuhua, G., 2015, 'Ethnobotanical survey of medicinal dietary plants used by the Naxi People in Lijiang Area, Northwest Yunnan, China', Journal Ethnobiology and Ethnomedicine 11(1), 40. https://doi.org/10.1186/s13002-015-0030-6

Zia-Ul-Haq, M., Stanković, M.S., Rizwan, K. \& De Feo, V., 2013, 'Grewia asiatica L., a food plant with multiple uses', Molecules 18(3), 2663-2682. https://doi. org $/ 10.3390 /$ molecules 18032663

Zongo, F., Ribuot, C., Boumendjel, A. \& Guissou, I., 2013, 'Botany, traditional uses, phytochemistry and pharmacology of Waltheria indica L. (syn. Waltheria americana): A review', Journal of Ethnopharmacology 148(121), 14-26. https:// doi.org/10.1016/j.jep.2013.03.080 